\title{
Prioritization of Key Activities on Establishment of BPM Practice in Apparel Organizations
}

\author{
Andrea Dobrosavljević, Snežana Urošević \\ University of Belgrade / Technical faculty in Bor / Vojske Jugoslavije 12, 19210 Bor
}

Corresponding Author: Andrea Dobrosavljević, an.dobrosavljevic@gmail.com

\begin{abstract}
The initial assumption within this paper is that successful implementation of business process management (BPM) practice in the apparel industry organizations depends on a set of priority steps and activities shaped by the specific characteristics of the apparel industry. The apparel industry is considered to be particularly specific because it has a labor-intensive and creative character, it is necessary to acquire certain professional knowledge and skills, the female workforce force is dominant, and micro, small and medium-sized enterprises (MSMEs) are present in the largest number. The aim of this paper is to perform prioritization and categorization of BPM practice establishment activities, based on the highlighted specifics, by integrating analytic hierarchy process (AHP), weighted aggregates sum product assessment and ABC analysis. The result showed that group A consists of 12 key activities, the first of which is the definition of process roles and responsibilities.
\end{abstract}

\author{
ARTICLE HISTORY \\ Received: 08.01.2020 \\ Accepted: 12.06.2020

\section{KEYWORDS} \\ Business process management \\ (BPM), apparel industry \\ specifics, AHP method, \\ WASPAS, ABC analysis
}

\section{INTRODUCTION}

The contemporary business sets a demand for organizations to implement adequate changes and to modernize their processes to maintain their position in the market, function in a stable manner, and establish the basis for continuous improvement. It is important to focus on business processes because they represent a set of business activities coordinated to ensure business goals achievement [1]. Business process management as a method of documenting, analyzing, modeling and simulating, functioning, and monitoring continuous changes of business processes from initial to final activities is a way for organizations to meet the requirements of contemporary business [2,3]. The way of carrying out activities within business processes is presented through a process model, which can be regarded from different perspectives, namely control flow, resource, data, time, and function perspective [4,5]. Comprehensive business process insights deliver value through the end-toend process [6].

To cite this article: Dobrosavljević A, Urošević S. 2020. Prioritization of key activities on establishment of bpm practice in apparel organizations. Tekstil ve Konfeksiyon, 30(3), 190-199.
The way BPM practice is applied varies across different business environments [7]. This paper focuses specifically on the apparel industry and the separation of primary activities to establish BPM in accordance with specific aspects of the industry. This research idea is the product of knowledge about the functioning of the apparel industry in Serbia and the region. The main products of the textile industry in Serbia nowadays are clothing (dresses, skirts, Tshirts, scarves, sweaters, socks, lingerie, pajamas, nightgowns, etc.), fashion details (bags, purses, wallets, belts, jackets, caps and other articles of leather), knits and yarns [8]. About $85 \%$ of textile products in North Macedonia are made by the garment industry [9]. The southwestern region of Bulgaria is characterized by the highest concentration of jobs in the textile and apparel industries [10]. Labor-intensive character with a predominantly female workforce and the need to educate 
professional staff through the cooperation of vocational schools and businesses, the seasonality of collections and creativity, are reflected in the business processes themselves. So, it can be stated that it is necessary to establish a BPM practice, and to adapt the business to the specified industry particularities [11,12]. This practice should be aimed at continuous improvement of business processes while monitoring the business trends of the market. As the success of an organization depends on the developed business model and its orientation [13], the need to form a framework for evaluation and adaptation of BPM practice, under the specific aspects of the industry, is observed within this paper. Business processes have a special role in the analysis and design of an organization, as well as creation of business system behavior patterns [14].

In line with the above mentioned, the aim of this paper is to evaluate and prioritize activities for adequate establishment of BPM in apparel industry organizations according to the specific aspects that determine the business within this industry. The structure of the paper is such that the theoretical part presents a literature review of the current research. The activities and apparel industry specifics, as a subject of research, are individually discussed in detail within the theoretical part of the paper. Within the research part of this paper, BPM activities are ranked, taking into account the estimated impact of specific aspects of the apparel industry. The Analytic Hierarchy Process (AHP) and Weighted Aggregates Sum Product Assessment (WASPAS) methods are performed, to assess the priority of the activities. The classification into the priority groups is managed using the ABC method, and a graphical representation of the classification is made using the Pareto diagram.

\section{ESTABLISHMENT OF BPM PRACTICE IN APPAREL ORGANIZATIONS}

To survive in the market, organizations need to coordinate and make changes in their production processes [15]. Adequate application of BPM ensures the achievement of flexibility and agility of the organization [16]. BPM is established with the aim to model processes and support their functioning with monitoring, audit, and analysis [17]. This practice drives the process of building a solution in an existing business environment [18].

BPM practices should be adaptable to the nature of business processes within a particular business system. Business systems within the apparel industry are characterized by several specifics, among which is the work intensity of the production process. Production of apparel products consists of a series of related labor-intensive manual operations [19]. The apparel industry can be described as a creative industry, dominated by a number of micro, small and medium-sized enterprises (MSMEs), and the growth of their competitiveness depends on the active acquisition and application of knowledge [20].
Kokeza and Urosevic [21] see the future development of the Serbian textile and apparel industry in the production of higher value-added products. The statement of these authors is consistent with the need to establish a business practice that is focused on delivering value-added results by managing processes that shape the result. Based on the stated findings, further elaboration of the prominent specifics of the clothing industry and activities relevant to the establishment of BPM practice continues.

\subsection{Specifics of the apparel industry}

Business processes that take place in the manufacturing organizations of the apparel industry include tailoring, sewing, button or zipper placement, ironing, quality control, packaging and shipping of goods to distributors and end consumers [14]. Work intensity, as one of the primary specifics of the apparel industry, is most clearly visualized within the process of assembling products, because the sewing line within this process contains a large number of operations [22]. Although the manufacturing process tends to be modernized and simplified by machines using CNC technology, the tailoring process is still performed manually in many companies [23].

Among apparel industry specifics arises the need for expertise and skills. Workforce productivity can be enhanced through training and the acquisition of effective skills [24]. Besides, learning how to produce something by hand is a particular type of talent or skill [25]. In the process of apparel production, it is necessary to know the techniques of sewing, but also to understand the material properties, the functioning of the sewing machines and what other equipment is necessary to perform the tasks in the process [26]. Urosevic et al. [27] state that the ability to integrate textile technology knowledge with other areas of business, the use of modern engineering tools, skills and techniques in practice, inventiveness and innovation in work, flexibility in behavior and similar, are the requirements for professional staff.

Another of the specifics of the apparel industry is creativity, which occurs in the process of the apparel product design. The highest level of creativity is attributed to the early stages of the design process, within which design principles such as harmony, rhythm, contrast, highlight, and proportion are combined and altered by the ideas that the designer develops [28].

There is a dominant share of the female workforce in laborintensive activities [29]. Especially in the apparel and textile industries where $70 \%$ of employed women are exposed to different types of risk [30].

Dallas and Wynn [31] consider establishing BPM in small organizations. In doing so, they highlight the characteristics of small businesses that can affect the level of BPM practice adoption. These characteristics are: limited human 
and financial resources, time pressure, narrow integration of activities, strong work ethics, and decision-making agility. Because a significant number of micro and SMEs operate within the apparel industry, these characteristics can influence the level of adoption of BPM practice in them. Chong [32] states that the role of BPM in SMEs is reflected in improving customer service, automating workflows and processes that already exist in the organization, informing employees of the activities they are in charge of with timely and accurate information on necessary measures, enabling the monitoring and optimization of business processes and the integration of tools for managing them.

\subsection{Activities according to key dimensions of BPM establishment}

Within the research conducted by Škrinjar and Trkman [33], elements related to the establishment of each of the dimensions concerning the functioning of BPM practices within organizations emerge. These authors present a range of activities applicable to the analysis of the process maturity of organizations operating within different industries [34]. A series of activities stems from the view that BPM is necessary to be addressed from a holistic perspective [35-37]. A holistic perspective on BPM encompasses organizational aspects such as human resource management, information systems, structure, sustainability, risk, decision-making, and knowledge along with alignment with business strategies [38].

Concerning human resources in an organization that implements BPM, employee knowledge and skills are considered essential resources for improving business processes, and learning is considered to be an important tool [32]. Börner et al. [39] emphasize the need to develop effective learning and training solutions with the intention of engaging employees to participate in process improvement initiatives. In doing so, they propose simulation as a training instrument because it provides a high degree of interaction between training participants with a realistic experience. Paul-Majumder and Begum [40] find that all jobs in the apparel industry require some level of education. One of the specifics of the apparel industry relates to the gender gap in employee education [41]. The textile industry in Serbia is faces a shortage of workforce that has the necessary skills and knowledge to complete tasks that certain jobs require [2]. Also, there is a gap in the application of theoretical and practical knowledge and skills of employees, a lack of knowledge of new technologies and a quality system, which makes education a necessary precondition for improving performance and productivity [42]. Training is a continuous process whereby an optimal combination of people, machines and materials occurs as the ultimate goal [43]. Not all work tasks, in the entire production process, can be automated, however, with the automatization of the tailoring processes, there is a need to acquire the practical skills and knowledge of handling new machines $[44,45]$. The innovative behavior of employees is closely linked to their creativity, but unlike creativity, it produces some kind of benefit [46]. Accordingly, stimulation for actors within creatively intensive processes should not be absent [47].

Operational activities related to BPM are often described as a lifecycle model. Starting with process identification where the process map is designed, then process discovery, analysis, and redesign, so that dedicated process-aware information systems can be implemented to support the execution of business processes. These information systems provide continuous process control and periodic control [48]. In the case of process-oriented information and communication technologies, it is more difficult to show the flow of information between all actors within the process as well as their responsibilities [49]. Organizations need a system to fulfill a few requirements. Among these requirements are a process-focused measurement system and a measurement system that would provide the measurement of quantitative and qualitative aspects of performance [50]. The flexibility of information systems is important because it provides support for the dynamic changes in processes [51]. The use of the internet and digital technologies ensures the collection and processing of data and information from customers, with the opportunity to develop strategies based on customer relationship management [52].

The focus on consumers as a dimension of BPM is significant, given the fact that the ultimate goal of managing business processes is to improve the process while optimizing value creation for customers [53]. The consumer-oriented business provides a continuous practice of creating value for customers based on the researched, expressed and hidden needs and desires of customers by applying different research techniques and methods [54]. Melcher [55] states that product complexity is subject to correction only by monitoring the external environment of the organization within which it comes to learn about different individual customer expectations and competitors' activities. If product development is based on consumer feedback, consumer satisfaction after the purchase can have a positive impact on repeated shopping in the future and the creation of a loyal customer base [56-58].

Process jobs refer to tasks and roles that occur in a processoriented organization. Multidimensionality and a frequent need to solve problems and a constant need for learning characterize them. Responsibilities are allocated horizontally in the structure, and the role of the owner over the whole process is assumed $[59,60]$.

Establishing a performance measurement system in an organization is carried out based on three basic steps that include definition, introduction to business and use of performance measures [61]. The organizations themselves are responsible for evaluating the organization's core and 
support processes and determining performance targets for each of them [62]. Employees, of organizations that apply BPM, become process participants with a broader range of responsibilities, perform the necessary activities and are tasked with performing multidimensional process tasks and must be familiar with targeted process performance $[63,60]$. Dobrosavljević and Urosević [64] find that establishing process improvement practices is the result of the experience organizations gain in business.

Min et al. [65] state that cooperation between a particular organization and a supplier is manifested in the form of inter-organizational business processes and as the basis of inter-organizational links. Legner and Wende [66] emphasize the need to coordinate inter-organizational business, and that even after coordination activities, additional challenges may arise concerning the interoperability of multiple business processes.

The use of process terminologies, such as input, process, output, or process owner, in daily communication between employees, results from the adoption of a process organizational culture within an organization [67]. Changes in business require a shift in the way people think. Those who adopt the process view more often work with people from other departments. This way of thinking characterizes information sharing, learning, and teamwork. It is necessary to create space for a culture of cooperation and an orientation towards meeting consumer needs [60].

Management activities include customer acceptance of orders, prototype modeling, customer approval, procurement of required fabrics and materials, production planning, organization resource management, employee performance management, and manufacturing management activities [14]. Production strategies should be subject to constant changes in line with changes in the business environment, but also in response to market needs due to the seasonality of collections [68].

In order to manage the business process at all, it is necessary to define it [69]. The definition of business processes is done by identifying and explaining the segments, or sets of activities, that make the functioning of the whole process possible. Cross-functional teams are designed to define the structure for managing processes and their implementation at the strategic level [70]. The description uses a standardized methodology that all employees should be familiar with in order to fulfill the requirements of the process functioning.

\section{MATERIAL AND METHOD}

\subsection{Material}

There is a different set of specific business aspects that characterizes each industry. The process orientation of an organization reflects through the different business dimensions and activities within each of them. An processoriented organization, which operates in a specific business environment, has to find the optimal way to establish a BPM practice. With that in mind, the need to generate a set of key activities for establishment of BPM pratice, taking into account the apparel industry specifics, arises. That is why the main elements of this research are apparel industry specifics and activities for establishment of BPM practice presented in the Figure 1. The specific aspects of the apparel industry, taken into consideration, are laborintensive and creative character, professional skills development, the dominant presence of female workforce in the production process, and a large number of micro and SMEs. It is assumed that specifics shape the way of doing business and that one universal set of activities will not produce successful results in all manufacturing and business systems. The specifics of the apparel industry may affect the priority of certain activities for the establishment of BPM practice. There are 39 recognized activities that might help establishment of BPM practice in described business environment listed in the Figure 1.

Each of the given activities for establishment of BPM practice, and the specifics of the apparel industry are evaluated by experts from the textile and apparel industry. Twenty-four experts from Serbia, North Macedonia, and Bulgaria participated in this research. Campagne et al. [71] disscuss the appropriate size of expert panel for reliablility of results. They state that the minimal number of experts should be between 10 and 15 , and they find that including 30 experts in the evaluation provides a stable mean. Consistent with these findings, it is considered that the number of 24 experts in the panel might provide reliable prioritization of the key activities for establishment of the BPM practice in apparel industry. The expertise of the experts is established on the basis of years of their experience in the production of textile and apparel and in educational institutions. Experts were asked to assess the impact of the apparel industry specifics having in mind impact on process input, process functioning, and process output, and then evaluate the importance of 39 activities for the establishment of BPM practice. Their estimates represent the input data of this research.

\subsection{Method}

Within this research the integration of the analytical hierarchy process (AHP) and weighted aggregated sum product assessment (WASPAS) was performed for prioritization of activities for the establishment of BPM practice. Weight coefficients of the apparel industry specifics were determined using the AHP method. This method is widely spread and useful in many decisionmaking problems [72]. In this case, it is used for calculation of weight coefficients of apparel industry specifics. Experts expressed preferences over specifics using the Saaty's nine 
point scale, where grade 1 stands for equal impact of two compared specifics, and 9 stands for absolute impact of one of two comapred specifics [73]. AHP allows the problem to be decomposed into levels of the decision-making hierarchy and uses pairwise comparisons for criteria and alternative evaluations, as well as weighitng cofficients computation [74,75]. As Fedrizzi and Brunelli [76] state, by the matrix of construction $\mathrm{A}=\left(a_{i j}\right)_{n x n}$ the relationship between the intensities of the alternatives of alternatives $\mathrm{x}_{i}$ and $\mathrm{x}_{j}$ is evaluated. Thereby, it is possible to assess the degree of consistency of the experts' responses. To do this, it is necessary to calculate a consistency index (CI) using the formula:

$C I=\frac{\lambda_{\max }-n}{n-1}$

Then, the degree of consistency is determined by the formula:

$C R=\frac{C I}{R I}$,

where RI is a Random Index (RI) that depends on the number of rows in the matrix denoted by $n$. The $C R$ value should not be higher than $0.1(10 \%)$ for the responses to be considered consistent [77]. The random index is read from Table 1.
After the calculation of the weight coefficients in the described manner, the third phase continues by application of Weighted Aggregates Sum Product Assesment (WASPAS) method. Chakraborty and Zavadskas [78] apply this method to decision making in production. The basic idea behind applying this method is in integration of weighted sum (WS) and weighted product (WP) approach to determine the significance of alternatives, or activities in this case. Activities were evaluated using a seven point scale, where grade 1 represents the lowest level of influence, i.e. insufficient significance, and grade 7 indicates the highest level of influence, ie absolute significance according to the defined elements of the research. Within WASPAS method the experts' ratings of activities and weight coefficients, generated by AHP method in previous research step, are combined to perform prioritization of activities for establishment of BPM practice according to evaluated impact of specifics. It is carried out in five steps. The first step is to determine the optimal level of performance with respect to each criterion by finding the maximum or minimum value according to the criterion under consideration. The second step is to normalize the decision matrix by the formula:

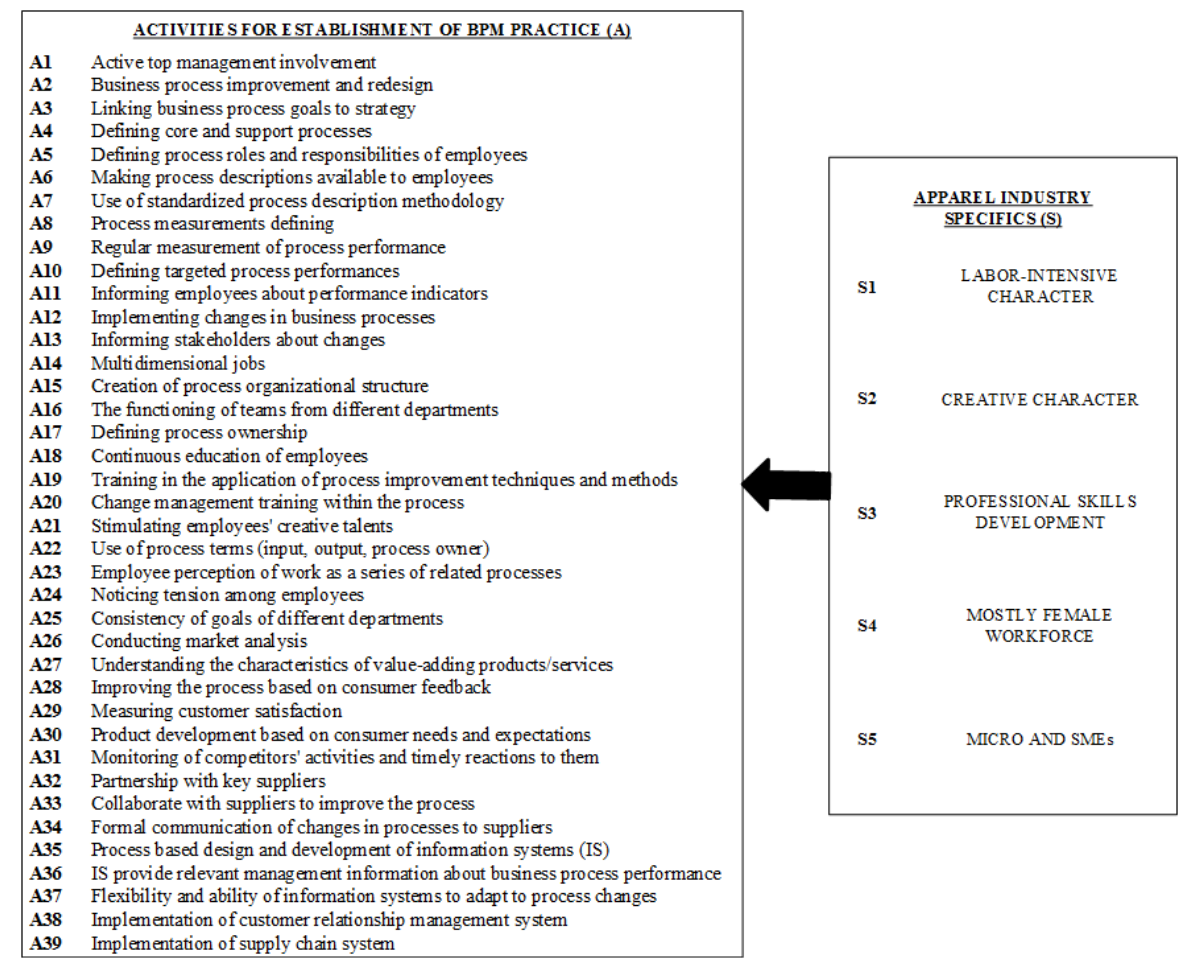

Figure 1. List of activities for establishing BPM practice and specifics of the apparel industry

Table 1. Random Index RI Values [77]

\begin{tabular}{llllllll}
\hline $\mathbf{N}$ & $\mathbf{1}$ & $\mathbf{2}$ & $\mathbf{3}$ & $\mathbf{4}$ & $\mathbf{5}$ & $\mathbf{6}$ & $\mathbf{7}$ \\
\hline $\mathrm{RI}$ & 0 & 0 & 0.58 & 0.90 & 1.12 & 1.24 & 1.32 \\
\hline
\end{tabular}


$r_{i j}= \begin{cases}\frac{x_{i j}}{x_{0 j}} ; & j \in \Omega_{\max } \\ \frac{x_{0 j}}{x_{i j}} ; & j \in \Omega_{\min }\end{cases}$

The third step is to calculate the relative importance $Q_{i}^{(I)}$ using the WS approach, while within the fourth step, the relative importance of the alternatives $Q_{i}^{(2)}$ is calculated using the WP approach according to the following formulas:

$$
\begin{aligned}
& Q_{i}^{(1)}=\sum_{j=1}^{n} w_{j} r_{i j} \\
& Q_{i}^{(2)}=\prod_{j=1}^{n} r_{i j}^{w_{j}}
\end{aligned}
$$

Finally, the fifth step considers the overall relative importance obtained by applying the formula:

$Q_{i}=\lambda Q_{i}^{(1)}+(1-\lambda) Q_{i}^{(2)}$,

where the value of the coefficient is $\lambda=0.5$ [79].

After prioritization, $\mathrm{ABC}$ analysis was applied to classify key activities for establishing BPM practice, and the situational presentation of the performed classification was presented in a Pareto diagram. More recent literature provides an example of the use of $\mathrm{ABC}$ chart analysis in ranking SME performance indicators as important data in the decision-making process [80]. This analysis is useful in the decision-making process because it enables the most influential elements to be highlighted and the elements with the least level of influence discarded, which contributes to the decision-making of the steps to be taken [32]. According to this analysis, the classification of research elements into $\mathrm{ABC}$ groups is most often done on the basis of one criterion, namely the value criterion [81].

The described methodology and the research flow within this paper is illustrated in Figure 2.

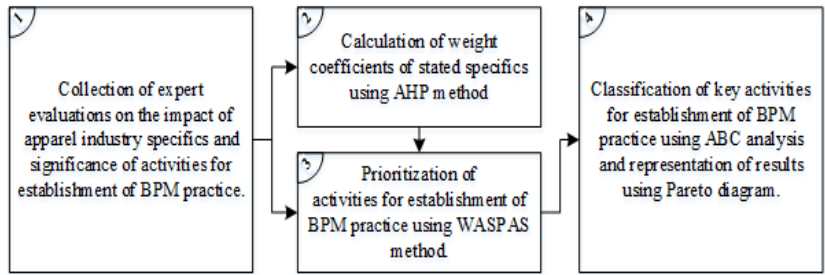

Figure 2. Research methodology and research flow

\section{RESULTS AND DISCUSSION}

Under the assumption that the business environment of the apparel industry is specific, research on providing the key set of priority activities for the establishment of continuous, efficient, and effective BPM practice is conducted. For this to be possible, data were collected based on the opinions of 24 experts, experienced in tasks related to production process management in business systems of different sizes and within educational and research institutions. Specific aspects were identified based on the generally known characteristics of the apparel industry, and experts had the opportunity to express their preferences about their impact. The mean scores of their responses on the significance of each specific aspect are presented in Table 2 .

Table 2. Mean values of expert assessments of specifics

\begin{tabular}{lc}
\hline \multicolumn{1}{c}{ Apparel industry specifics } & Mean values \\
\hline S1 - Labor-intensive character & 6.250 \\
S2 - Creative character & 4.458 \\
S3 - Pofessional skills development & 5.583 \\
S4 - Mostly female workforce & 5.083 \\
S5 - Micro and SMEs & 2.625 \\
\hline
\end{tabular}

The labor-intensive character was evaluated as a criterion of very strong significance in the functioning of the apparel industry processes, as core processes are the ones characterized by labor intensity. According to the expressed preferences of the experts from the presented mean values, the criteria are arranged in descending order, namely: S1 S3 - S4 - S2 - S5. In order to effectively evaluate and prioritize activities, which in such a specific environment will accelerate the adoption of BPM principles and ensure business success, the weight coefficients of specific aspects are determined. For determination of weight coefficients of specifics, a decision-making hierarchy, within the AHP method, is defined. The goal is to calculate weight coefficients of apparel industry specifics, the first level considers the criteria of impact on process input, process functioning, and process output, and the specifics are evaluated in the second level of the decision-making hierarchy. According to the described procedure, pairwise comparison at both hierarchy levels was applied.

The pairwise comparison matrix shown in Table 3. Represents the expressed preferences of experts at the second level. The diagonal is a value of 1 , which indicates equal significance when comparing the same specific aspect.

Table 3. Pairwise comparison matrix at second level of decisionmaking hierarchy and calculated weights of apparel industry specifics

\begin{tabular}{lllllll}
\hline & S1 & S3 & S4 & S2 & S5 & $\begin{array}{l}\text { Weig } \\
\text { hts }\end{array}$ \\
\hline S1 & 1 & 0.67 & 1.17 & 1.79 & 3.63 & 0.258 \\
S3 & 1.50 & 1 & 0.50 & 1.13 & 2.63 & 0.223 \\
S4 & 0.86 & 2 & 1 & 0.63 & 2.46 & 0.232 \\
S2 & 0.56 & 0.89 & 1.60 & 1 & 1.83 & 0.202 \\
S5 & 0.28 & 0.38 & 0.41 & 0.55 & 1 & 0.085 \\
\hline \multicolumn{7}{c}{ CR $=0.06$} \\
\hline
\end{tabular}

The estimated consistency ratio (CR) in the responses of experts, based on the application of formulas (2) and (3) in 
the first level is 0.003 or $0.3 \%$, and in the second level is 0.06 , or $6 \%$, which are less than the recommended value of 0.1 , or $10 \%$, respectively. Based on which it is concluded that consistency in the experts' answers, that is, a certain degree of agreement in the assessments of a group of experts, has been achieved. The criterion of labor intensity appears as one of the most influential among the specifics. The lowest rated aspect is the size of organizations operating in the apparel industry. The dominant presence of SMEs is characteristic of other industries as well. Starting with the assumption that the character of an industry can be reflected in the business processes, the prioritization of activities in the next step of the research is approached. Evaluated specifics are further treated as criteria in the research.

Based on the obtained weight coefficients and expert evaluations of each activity against the set criteria, the
WASPAS method is implemented according to the described procedure. The final level of performance and the degree of utility of the considered activities were obtained by applying formula (6), which is shown in Table 4.

The degree of utility provides insight into the significance of each activity. The activity of the priority importance, according to the ranking result, is to define process roles and responsibilities. This activity is considered to be an initial activity in the characteristic business environment of the apparel industry.

ABC analysis was applied, as a final step. It provides the classification of ranked activities into the activity sets with a priority of the application. However, a graphical representation can provide a better insight into the order and impact of the activity, so the classification result is shown on the Pareto diagram in Figure 3.

Table 4. The resulting level of performance and the degree of utility of the considered activities

\begin{tabular}{|c|c|c|c|c|c|c|c|c|c|}
\hline Activity & $\mathbf{Q i}^{(1)}$ & $\mathbf{Q i}^{(2)}$ & $\mathbf{Q i}$ & Rank & Activity & $\mathbf{Q i}^{(\mathbf{l})}$ & $\mathbf{Q i}^{(2)}$ & Qi & Rank \\
\hline A1 & 0.807 & 0.685 & 0.746 & 4 & A21 & 0.386 & 0.360 & 0.373 & 25 \\
\hline A2 & 0.387 & 0.307 & 0.347 & 31 & A22 & 0.396 & 0.317 & 0.356 & 28 \\
\hline A3 & 0.390 & 0.372 & 0.381 & 21 & A 23 & 0.421 & 0.417 & 0.419 & 18 \\
\hline A4 & 0.674 & 0.609 & 0.641 & 10 & A24 & 0.387 & 0.363 & 0.375 & 24 \\
\hline A5 & 0.832 & 0.698 & 0.765 & 1 & A25 & 0.399 & 0.320 & 0.359 & 26 \\
\hline A6 & 0.378 & 0.296 & 0.337 & 34 & A26 & 0.384 & 0.303 & 0.344 & 32 \\
\hline A7 & 0.366 & 0.282 & 0.324 & 38 & A27 & 0.394 & 0.378 & 0.386 & 20 \\
\hline A8 & 0.739 & 0.638 & 0.689 & 8 & A 28 & 0.427 & 0.423 & 0.425 & 17 \\
\hline A9 & 0.507 & 0.495 & 0.501 & 15 & A29 & 0.399 & 0.320 & 0.359 & 27 \\
\hline A10 & 0.665 & 0.603 & 0.634 & 12 & A30 & 0.389 & 0.369 & 0.379 & 22 \\
\hline A11 & 0.525 & 0.508 & 0.516 & 13 & A31 & 0.393 & 0.313 & 0.353 & 29 \\
\hline A12 & 0.375 & 0.293 & 0.334 & 35 & A32 & 0.415 & 0.410 & 0.412 & 19 \\
\hline A13 & 0.372 & 0.289 & 0.331 & 36 & A33 & 0.516 & 0.501 & 0.509 & 14 \\
\hline A14 & 0.360 & 0.274 & 0.317 & 39 & A34 & 0.372 & 0.289 & 0.331 & 36 \\
\hline A15 & 0.498 & 0.488 & 0.493 & 16 & A35 & 0.679 & 0.612 & 0.645 & 9 \\
\hline A16 & 0.388 & 0.366 & 0.377 & 23 & A36 & 0.802 & 0.682 & 0.742 & 5 \\
\hline A17 & 0.827 & 0.695 & 0.761 & 2 & A37 & 0.812 & 0.687 & 0.750 & 3 \\
\hline A18 & 0.669 & 0.606 & 0.638 & 11 & A38 & 0.390 & 0.310 & 0.350 & 30 \\
\hline A19 & 0.749 & 0.644 & 0.696 & 7 & A39 & 0.381 & 0.300 & 0.340 & 33 \\
\hline A 20 & 0.757 & 0.648 & 0.702 & 6 & & & & & \\
\hline
\end{tabular}

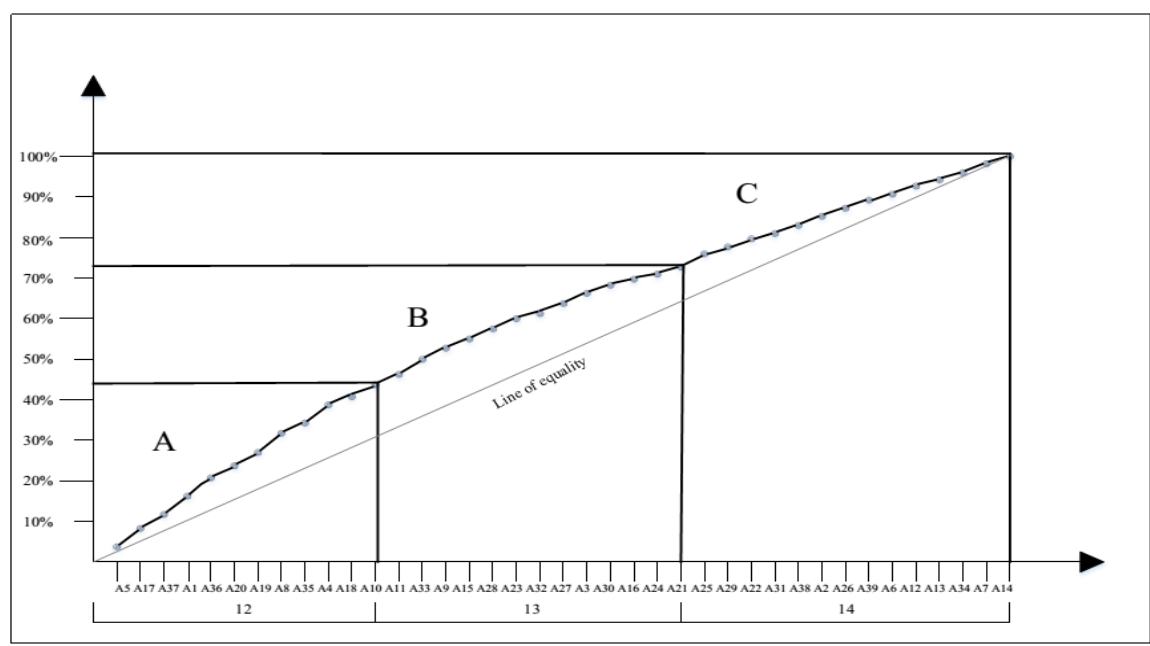

Figure 3. Situational presentation of the classification of key activities using the Pareto diagram 
The rule according to which elements are classified A, B, and $\mathrm{C}$, in most cases applied in inventory management cases, is $80-20$. This means that $20 \%$ of items contribute to a business result with $80 \%$ of the value $[82,83]$. However, in this case, it is not a matter of monetary value. The activities were evaluated based on experts' assessments, and their value is an expression of opinion on potential impact or significance. The ranked values are approximate, although different. The Pareto diagram presents an equality line, which would indicate perfect equality of influence of the considered elements of the analysis, to notice the presence in the difference of activity influence compared to it [84]. In this case, the first 12 activities contribute with $44.88 \%$, according to the rule that the A group contains the lowest number of elements with the highest percentage of contributions, and it is not possible to adhere to the same rule used in inventory management cases, the line is underlined here and these elements are classified as elements of group A. This is a group of key activities that should be implemented for successful establishment of BPM practice. Therefore, in addition to defining process roles and responsibilities, activities that define process ownership (A17) are included here. These are followed by the flexibility and ability of information systems to adapt to process changes (A37), actively engaging top management (A1), obtaining relevant managerial information on process performance through information systems (A36), conducting training for change management within the process (A20), conducting training in the application of process improvement techniques and methods (A19), defining process measures (A8), designing and developing a process-based information system (A35), defining core and support processes (A4), continuous employee education (A18), and defining targeted process performances (A10). It can be seen from the presented that the primary activities are focused on the definition of business process management systems, the functioning of information systems to support the realization of processes, employees, and the development of their skills and knowledge and setting goals related to process performance.

\section{CONCLUSION}

In the search for best business practice, one can come across models that can be successful within some business systems. But it doesn't necessarily mean that they are universally applicable and equally successful everywhere. Consideration of apparel industry specifics may contribute to the adaptation of activities for best business practice implementation. Taking into account the specific aspects of the business environment in the apparel industry, within this paper, the procedure for establishing BPM practice was explored. Accordingly, 39 activities that influence the establishment of this practice were ranked on the basis of specific aspects by integrating methods AHP and WASPAS. Final categorization of key activities for establishment of BPM practice in the apparel industry organizations was done using $\mathrm{ABC}$ analysis. The final result of the extracting a set of 12 activities was presented using Pareto diagram. Based on this procedure, group A consists of a series of activities related to defining the responsibility, knowledge, and skills of employees, defining targeted process performance and forming a functional information system to support the process realization. Following the state of the business environment in the industry can provide information for the selection of adequate activities not only for implementation but also for management and improvement efforts. Future research will focus on a more detailed analysis of the priority activities, that were prioritized in this research. Also, taking into account the responses from employees in the apparel industry, the model that contributes to establishing sound business process management in the apparel industry, and improving overall business performance based on process improvements will be developed.

\section{REFERENCES}

1. Awad A, Weidlich M, Weske M. 2011. Visually specifying compliance rules and explaining their violations for business processes. Journal of Visual Languages \& Computing 22(1), 30-55.

2. Pardanjac M, Jokić S, Stanisavljev S, Zubanov V, Tasić I, Milanov D. 2017. Preconditions for Setting up E-training for SME Textile Companies in Serbia, Chapter 3. In Katalinic, B. (Ed.), DAAAM International Scientific Book. Vienna, Austria: DAAAM International, 029-042.

3. Bitkowska A. 2016. Knowledge management vs business process management in contemporary enterprises. Ekonomia $i$ Zarzadzanie $8(2), 31-37$.

4. Cayoglu U, Dijkman R, Dumas M, Fettke P, García-Bañuelos L, Hake P, ... Mendling J. 2013. August. The process model matching contest 2013. In Lohmann, N, Song, M, Wohed, P. (Eds.), Proceedings of the $11^{\text {th }}$ International Conference on Business Process Management (442-463). Beijing, China.

5. Aalst W. 2013. Business process management: a comprehensive survey. ISRN Software Engineering, 1-37.

6. Lambert D. M. 2010. Customer relationship management as a business process. Journal of Business \& Industrial Marketing 25(1), 4-17.

7. Bucher T, Winter R. 2010. Taxonomy of business process management approaches. In vom Brocke J., Rosemann M. (Eds.), Handbook on Business Process Management 2. Springer Berlin, Heidelberg, 93-114.

8. Jordeva S, Tomovska E, Trajković D, Zafirova K. 2015. Current state of pre-consumer apparel waste management in Macedonia. Fibres \& Textiles in Eastern Europe, 23, 1(109), 13-16.

9. Mladenova G. 2016. Marketing strategy of apparel and textile cluster in southwest region of Bulgaria. Acta Universitatis Lodziensis. Folia Oeconomica 2(320), 65-74.

10. Kabukcu E. 2015. Creativity process in innovation oriented entrepreneurship: The case of Vakko. Procedia-Social and Behavioral Sciences 195, 1321-1329. 
11. Vinčić A. 2018. U Varaždinu održan Okrugli stol: Potreba za obrazovanjem u sektoru tekstil/odjeća/koža/obuća u sjeverozapadnoj Hrvatskoj. Tekstil: časopis za tekstilnu tehnologiju i konfekciju 67(56), 155-159.

12. Patora-Wysocka Z. 2015. Inhibitors of restructuring change in Textile and apparel enterprises. Fibres \& Textiles in Eastern Europe 5 (113), 8-12.

13. Böhnlein M, Ulbrich-vom Ende A. 2000. Business process oriented development of data warehouse structures. In Jung, R, Winter, R. (Eds.), Data Warehousing 2000. Physica, Heidelberg, 3-21.

14. Gökalp E, Gökalp MO, Eren PE. 2018. Industry 4.0 Revolution in Clothing and Apparel Factories: Apparel 4.0. Içinde Industry 4, 169183

15. Kansul DS, Karabay G. 2019. Increasing the process cycle efficiency of men's trousers assembly line. Tekstil ve Konfeksiyon 29(3), 253262

16. Gong, Y, Janssen, M. 2012. From policy implementation to business process management: Principles for creating flexibility and agility. Government Information Quarterly 29, 61-71.

17. Fantinato M, Gimenes IDS, Toledo MB. 2010. Product line in the business process management domain. Applied software product line engineering, 497-530.

18. Matejaš M, Fertalj K. 2018. Building a BPM Application in an SOABased Legacy Environment. Computer Science and Information Systems 16(1), 45-74.

19. Hassler M. 2003. The global clothing production system: commodity chains and business networks. Global networks 3(4), 513-531.

20. Urošević S, Dobrosavljević A. 2019. Conditions of development of small and medium enterprises in clothing industry, In Mihajlović, I. (Ed.), Monography: How to prevent SMEs failure (Actions based on comparative analysis in Višegrad countries and Serbia), University of Belgrade, Technical Faculty in Bor, Engineering Management Department (EMD), 583 - 627.

21. Kokeza G, Urošević S. 2018. Strateški pravci razvoja tekstilne odevne industrije u Republici Srbiji, Tekstilna industrija 66(4), 6978 .

22. Rajput D, Kakde M, Chandurkar P, Raichurkar PP. 2018. Enhancing Efficiency and Productivity of Garment Industry by Using Different Techniques. International Journal on Textile Engineering and Processes 4(1), 5-8.

23. Şen Kılıç A. 2019. Comparison of Cad and Manual System Efficiency In Pre-Production Preparation Process. Tekstil ve Konfeksiyon 29 (1), 67-77.

24. Jain D, Jain P. 2012. November. Sustainable Business PracticesEnablers \& Barriers in the Indian Apparel Industry. In Conference proceeding of the National conference on Paradigm for Sustainable Business: People, Planet and Profit held at DOMS, IIT Roorkee.

25. Goodman E, Rosner D. 2011. May. From garments to gardens: negotiating material relationships online and'by hand'. In Tan D (Ed.), Proceedings of the CHI'11: CHI Conference on Human Factors in Computing Systems, Vancouver, Canada: Association for Computing Machinery, New York, United States, 2257-2266.

26. Cole J, Czachor S. 2014. Professional sewing techniques for designers. A\&C Black

27. Urošević S, Cvijanović JM, Đorđević D. 2008. Unapređenje obrazovnog nivoa zaposlenih $\mathrm{u}$ tekstilnoj industriji Srbije. Industrija 36(3), 79-105.

28. Lee JS, Jirousek C. 2015. The development of design ideas in the early apparel design process: a pilot study. International Journal of Fashion Design, Technology and Education 8(2), 151-161.

29. Kucera D, Tejani S. 2014. Feminization, defeminization, and structural change in manufacturing. World Development 64, 569-582.

30. Stefanović V, Urošević S, Mladenović-Ranisavljević I, Stojilković P. 2019. Multi-criteria ranking of workplaces from the aspect of risk assessment in the production processes in which women are employed. Safety science 116, 116-126.
31. Dallas I, Wynn MT. 2014. Business process management in small business: a case study. In Devos J, et al. (Eds.), Information Systems for Small and Medium-sized Enterprises. Springer, Berlin, Heidelberg, 25-46.

32. Chong S. 2014. Business process management for SMEs: an exploratory study of implementation factors for the Australian wine industry. Journal of Information Systems and Small Business 1(1-2), 41-58.

33. Škrinjar R, Trkman P. 2013. Increasing process orientation with business process management: Critical practices'. International Journal of Information Management 33(1), 48-60.

34. Glavan LM, Vukšić VB. 2017. Examining the impact of business process orientation on organizational performance: the case of Croatia. Croatian Operational Research Review 8(1), 137-165.

35. Vugec DS, Vukšić VB, Glavan LM. 2017. Social Business Process Management and Business Process Management Maturity. International Journal of Economics and Management Engineering 11(5), 1122-1126.

36. Rosemann M., de Bruin T. 2005. Application of a holistic model for determining BPM maturity. BP Trends 2, 1-21.

37. Karagiannis D. 2012. June. Business process management: A holistic management approach. In Mayr HC, Kop C, Liddle S, Ginige A (Eds.) Information Systems: Methods, Models, and Applications. UNISCON 2012. Lecture Notes in Business Information Processing, vol 137. Springer, Berlin, Heidelberg, 1-12

38. Seethamraju R. 2012. Business process management: a missing link in business education. Business Process Management Journal 18(3), 532-547.

39. Börner R, Moormann J, Wang M. 2012. Staff training for business process improvement: The benefit of role-plays in the case of KreditSim. Journal of Workplace Learning 24(3), 200-225.

40. Paul-Majumder P, Begum, A. 2000. The gender imbalances in the export oriented garment industry in Bangladesh (Working Paper Series No. 12). Washington, DC: World Bank, Development Research Group/Poverty Reduction and Economic Management Network.

41. Hossain MA, Tisdell CA. 2005. Closing the gender gap in Bangladesh: inequality in education, employment and earnings. International Journal of Social Economics 32(5), 439-453.

42. Đorđević D, Urošević S, Cvijanović JM. 2010. Uloga klastera u unapređivanju konkuretnosti tekstilne i odevne industrije u Republici Srbiji. Industrija 38(2), 177-198.

43. Srivastava NA, Chatterjii A. 2014. Skills requirement analysis at the production floor in ready-made garment industry. Asian journal of management sciences \& education 3(1), 23-34.

44. Sundstrup E, Jakobsen MD, Andersen CH, Jay K, Persson R, Aagaard P, Andersen, LL. 2013. Participatory ergonomic intervention versus strength training on chronic pain and work disability in slaughterhouse workers: study protocol for a singleblind, randomized controlled trial. BMC musculoskeletal disorders 14(1), 67.

45. Nemeša I. 2019. Organizacija radnih procesa u krojačnici uz pomoć automatizovanih sistema menadžmenta, Tekstilna industrija 67(2), 45-49.

46. De Jong JP, Den Hartog DN. 2007. How leaders influence employees' innovative behaviour. European Journal of innovation management 10(1), 41-64.

47. Seidel S, Shortland K, Elzinga D. 2010. Managing creativityintensive processes: learning from film and visual effects production. In vom Brocke J, Rosemann M. (Eds.), Handbook on Business Process Management 2, Springer, Berlin, Heidelberg, 515-538.

48. Malinova M, Mendling J. 2018. Identifying do's and don'ts using the integrated business process management framework. Business Process Management Journal 24(4), 882-899.

49. Berg M, Toussaint P. 2003. The mantra of modeling and the forgotten powers of paper: a sociotechnical view on the development of process-oriented ICT in health care. International journal of medical informatics 69(2-3), 223-234. 
50. Kueng P. 2000. Process performance measurement system: a tool to support process-based organizations. Total Quality Management 11(1), 67-85.

51. Reichert M, Weber B. 2012. Enabling flexibility in process-aware information systems: challenges, methods, technologies. Springer Science \& Business Media.

52. Arrigo E. 2018. Customer Relationships and Supply Chain Management in the Fast Fashion Industry. In Lee I (Ed.), Diverse Methods in Customer Relationship Marketing and Management. IGI Global, 1-16.

53. Conger S. 2015. Six sigma and business process management. In Rosemann M (Ed.), Handbook on Business Process Management 1. Springer, Berlin, Heidelberg, 127-146.

54. Alam I, Perry C. 2002. A customer-oriented new service development process. Journal of services Marketing 16(6), 515-534.

55. Melcher J. 2014. Process measurement in business process management: Theoretical framework and analysis of several aspects. KIT Scientific Publishing.

56. Irani N, Hanzaee KH. 2011. The effects of variety-seeking buying tendency and price sensitivity on utilitarian and hedonic value in apparel shopping satisfaction. International Journal of Marketing Studies 3(3), 89

57. Parrish ED, Cassill NL, Oxenham W. 2006. Niche market strategy in the textile and apparel industry. Journal of Fashion Marketing and Management: An International Journal 10(4), 420-432.

58. Kaulio MA. 1998. Customer, consumer and user involvement in product development: A framework and a review of selected methods. Total quality management 9(1), 141-149.

59. Mijoska M, Levkov N. 2015. May. Business process orientation construct analysis in companies in the Republic of Macedonia. In Biljanović P, et al. (Eds.). Proceedings of the 38th International Convention on Information and Communication, Technology, Electronics and Microelectronics, MIPRO 2015 (1829-1834). Opatija, Croatia.

60. Eicker S, Kochbeck J, Schuler PM. 2008. May. Employee competencies for business process management. In Abramowicz W (Ed.), Proceedings of the 11th International Conference Business Information Systems, BIS 2008 (251-262). Innsbruck, Austria.

61. Bourne M, Mills J, Wilcox M, Neely A, Platts K. 2000. Designing, implementing and updating performance measurement systems. International journal of operations \& production management 20(7), 754-771.

62. Amaratunga D, Baldry D, Sarshar M. 2001. Process improvement through performance measurement: the balanced scorecard methodology, Work study 50(5), 179-189.

63. Weske M. (2012). Business process management architectures. In Weske M (Ed.), Business Process Management. Springer, Berlin, Heidelberg, 333-371.

64. Dobrosavljević AU, Urošević SM. 2019. Evaluation of orientation on performances and process improvements in manufacturing organizations. Tehnika 74(2), 287-294.

65. Min S, Roath AS, Daugherty PJ, Genchev SE, Chen H, Arndt AD, Glenn Richey R. 2005. Supply chain collaboration: what's happening?. The international journal of logistics management 16(2), $237-256$.

66. Legner C, Wende K. 2007. June. The challenges of interorganizational business process design-a research agenda. In
Proceedings of the European Conference on Information Systems, ECIS 2007, (106-118). St Gallen, Switzerland.

67. McCormack K, Willems J, Van den Bergh J, Deschoolmeester D, Willaert P, Indihar Štemberger M, ... Bosilj Vuksic V. 2009. A global investigation of key turning points in business process maturity. Business Process Management Journal 15(5), 792-815.

68. Lin SH, Moore MA, Kincade DH, Avery C. 2002. Dimensions of apparel manufacturing strategy and production management. International Journal of Clothing Science and Technology 14(1), 4660.

69. Chang JF. 2016. Business process management systems: strategy and implementation. Auerbach Publications.

70. Lambert DM, García-Dastugue SJ, Croxton KL. 2005. An evaluation of process-oriented supply chain management frameworks. Journal of business Logistics 26(1), 25-51.

71. Campagne CS, Roche P, Gosselin F, Tschanz L, Tatoni T. 2017. Expert-based ecosystem services capacity matrices: Dealing with scoring variability. Ecological Indicators, 79, 63-72.

72. Ishizaka A, Pearman C, Nemery P. 2012. AHPSort: an AHP-based method for sorting problems. International Journal of Production Research, 50(17), 4767-4784.

73. Guh YY, Po RW, Lou KR. 2009. An additive scale model for the analytic hierarchy process. International journal of information and management sciences, 20(1), 71-88.

74. Dulange SR, Pundir AK, Ganapathy L. 2014. Prioritization of factors impacting on performance of power looms using AHP. Journal of Industrial Engineering International, 10(4), 217-227.

75. Cavallo B, D'Apuzzo L. 2009. A general unified framework for pairwise comparison matrices in multicriterial methods. International Journal of Intelligent Systems 24(4), 377-398.

76. Fedrizzi M, Brunelli M. 2010. On the priority vector associated with a reciprocal relation and a pairwise comparison matrix. Soft Computing 14(6), 639-645.

77. Franek J, Kresta A. 2014. Judgment scales and consistency measure in AHP. Procedia Economics and Finance 12, 164-173.

78. Chakraborty S, Zavadskas EK. 2014. Applications of WASPAS method in manufacturing decision making. Informatica 25(1), 1-20.

79. Stanujkić D, Karabašević D. 2018. An extension of the WASPAS method for decision-making problems with intuitionistic fuzzy numbers: A case of website evaluation. Operational Research in Engineering Sciences: Theory and Applications 1(1), 29-39.

80. Gawlik R. 2019. Ranking of company performance indicators for managerial decision making purposes with application of the Delphi method. Studia $i$ Materiaty Wydziatu Zarzadzania $i$ Administracji Wyższej Szkoły Pedagogicznej im. Jana Kochanowskiego w Kielcach "Miscellanea Oeconomicae" , 1 (23), 177-188.

81. Boukili A, Fri M, El Hammoumi M, Belmajdoub F. 2016. Elaboration of a new method in the science of decision. International Journal of Scientific and Engineering Researc 7(4), 1334-1338.

82. Flores BE, Whybark DC. 1987. Implementing multiple criteria ABC analysis. Journal of Operations Management 7(1-2), 79-85.

83. Stojanović M, Regodić D. 2017. The Significance of the Integrated Multicriteria ABC-XYZ Method for the Inventory Management Process. Acta Polytechnica Hungarica 14(5), 29-48.

84. Dunford R, Su Q, Tamang E. 2014. The Pareto Principle. The Plymouth Student Scientist 7(1), 140-148. 